UDC 330.4

(C) 2017

\title{
Innovations in development of agrarian factories in Zakarpattia oblast
}

\author{
H. Spaskyi, \\ Doctor of Economic Sciences \\ Zakarpattya State Agricultural Experimental Station, NAAS
}

The purpose. To determine nature and features of agrarian innovations for delineating directions of activation of innovative activity of agrarian factories at regional level. Methods. Monographic, calculation, mathematicalstatistical. Results. Agricultural innovation can be considered as innovation in the field of agriculture that is accompanied by deriving mercantile effect. Specificity of innovations in agrarian production is stipulated by features of agriculture where the major factor of production is the land. Innovative activity in agriculture has 4 stages: development of innovations, their approbation, testing and procreation, implementation into production. Conclusions. The most weighable cause of retardation of process of implementation of agricultural innovations is insufficient level of financial security of factories, low accessibility of credits and state support for modernizing agrarian branch, backwardness of system of data support of innovative process.

Key words: agricultural innovations, investment security, agrarian factories, agriculture, efficiency, technological parks.

Problem setting. Topicality of investigation of the innovative activity of the agricultural enterprises is conditioned by the strengthening of the competitive struggle on the market of agricultural production and integration of Ukraine into the international economic area, which preconditions the necessity of forming the innovation - investment model of agricultural development.

The practice of innovations, on the one hand, witnesses that on their way there are a lot of complications that essentially slow down the innovative development in the state, on the other side that innovative development is becoming, and in some aspects had already established as a strategic one for the development of branches and regions. However, these steps demand a concrete filling, from the organization of personnel preparation to the practical realization of the scale innovative projects and programs.

A set of principal questions of innovative development of agriculture has not been defined yet, especially, the mechanisms of stimulating and state support of innovative activity, increase of the commercial possibilities of innovative elaborations financing and venture entrepreneurship, deepening of the informative and economic relations between science and production in the process of intellectual property usage, regional aspects of innovation process in the agrarian sphere. In the contemporary conditions the innovative the development of the enterprises of the agrarian sphere is possible only on the bases of a corresponding model which has to take into consideration the regional peculiarities of agro industrial production and possibilities of innovative development. The establishment of the innovative models of agrarian production development is a system problem.

Economics, society, production depend on innovations, because they possess the peculiarities of improving, organizing, increasing the efficiency of correlation in the creation of an additional product. 11].

Innovations in the agro industrial production - are firstly the new sorts of plants, breeds of animals, and cross breeding of birds, new fertilizers, and means of plants and animals protection, modern 
technics, new methods of prophylaxis and treating of animals, technologies, forms of organization and financing the production, approaches to personnel training. [13].

Analysis of the latter investigations and publications. An important role in the theoretical and practical research of the questions of organization of investment - innovative activity of state and entrepreneurship and their influence on the development of the national household play the works of the contemporary home scientists and practicians: A.I.Gordiychuk [2], V.P.Gordiyenko [3], Y.M.Bazhala [2], I.V. Odotyk [5], M.S. Danko[5], O.O. Lapko[5], O.I. Datziy[4], O.V. Kot[6], M.V. Zubetz[7] and others. A considerable attention to the observation of innovations is given by the famous scientists A.V.Balyan, [1], Sabluk P.T. [10], Santo B. [11], Tregobchuk V. [13], O.V. Shkilyov [15], V.G. Chaban [14], B. Obama[8].and others.

In the works of the investigators the questions of theory, methodology of forming the backgrounds of innovative development of the production sphere, which foresee the study of aspects of innovative development on the agrarian market are being shown.

Giving credit for results of investigations and their role in enrichment of innovative paradigm of development, still there should be mentioned that to the given subject plane of researches there hadn't been included the regional context, and the specification of innovative development of agricultural production hasn't been covered enough, which lies in the fact, that simultaneously with the use of innovative technologies there should be taken into consideration the social-economic factors of employment of population, development of the neighboring branches(plant science, animal farming) and exclusion of the decrease of soil productivity.

In the conditions of limiting the financial possibilities necessary is a precise definition of priorities of the home innovative development for the aim oriented and efficient capital investments that need the research of the conditions in which the innovative processes take place on the enterprises of the agrarian sector. [5].

The aim of the given article is defying the essence and peculiarities of the agrarian innovations for outlining on this basis the directions of activation of innovative activity of the agrarian enterprises on the regional level.

Exposition of the basic materials of investigation. Peculiar feature of the innovative technologies implementation in the agrarian enterprises is a huge variety of producers: farmer households, agrarian enterprises of different forms of organization. Besides the mentioned above business entities during the last years various big holdings had been created. All these organizational structures work on the rentable lands with the various areas of agricultural lands - from 2 to 10000 hectares. In the mentioned above structures the basic means of production had become the lands, taken on lease from the small holders ( shares rent) [6].

For each nature-climate zone the scientists had calculated the optimal sizes of agricultural lands of the agrarian formations which for example on Polissya (forest area) and in forest-steppe should be not less than 2000 ha, and for the Carpathians and Fore-Carpathians- 1000 ha, as when widening the crop acreage, the profitability of production of plant and animal production will increase only till the certain measures.

Nowadays, in a wide sense agro innovation is a novation which is being realized in the agrarian production.

The scientists propose various approaches to definition of this notion. Thus, agro innovation is being treated both as a systematic implementation into the agrarian entrepreneurship of the results of scientific-research work, which lead to the positive qualitative and quantitative changes in the characteristics of correlations between the biosphere and techno sphere and also improve the state of environment, and as a result of work gained thanks to the use of the new scientific knowledge which 
change the process of functioning and development of household-production activity in the direction of increase of its efficiency, resistibility and system quality of relations. [4].

With the help of investigations, there had been established that agro innovation can be treated as the new notion in the branch of agriculture (kinds of plants, breeds of animals, means of plants or animals protection, growing technologies), which is accompanied with the gaining of a commercial effect.

The specifics of innovations in the agrarian production is preconditioned by the peculiarities of the very agriculture, where the basic factor of production is the land, in the process of production there is a precise correlation with the living organisms( plants, animals), the production has a seasonal character and a high risks level. With implementation of innovations into the branch, the types of production, as a rule, won't be changed, only will gain the improved characteristics. The innovative activity in agriculture can be viewed on the four stages: elaboration of innovations, their approbation and checking, reproduction of innovations and their implementation into production.

However, the innovative development of the agrarian enterprises is impossible without the sufficient financial provision.

A key problem is a problem of involving the investments resources into the innovative development and their rational usage and upon the solving of this problem depend the possibilities of the further economic growth of the agrarian enterprises.

A constant investments deficit, preconditioned by the reduction of the state financial support of the agricultural enterprises, absence of the developed financial-credit infrastructure, change of the dominants of the state agrarian policy, conditioned by the enlistment of Ukraine into WTO, permanent increase of price disparity on the industrial and agricultural production, high level of ageing of material-technical base of agrarian enterprises, low investment attraction of the separate segments of the agrarian sphere - is a factual basic barrier for activation of innovative demand of the agrarian goods producers. [9].

In the agricultural enterprises of Transcarpathia the part of a produced by them gross production is less than in the households of population, and during 2006-2015 increased from 4,6 to 7,6\% under its general growth on $9,5 \%$.

In 2015 all the agrarian formations of Transcarpathian region as a result got only $233,1 \mathrm{mln} \mathrm{hrn}$ income, which witnesses on the low profitable and unprofitable production of agricultural goods in the majority of enterprises. (table. 1).

1. Dynamics of economic efficiency of production of basic types of goods in the agricultural enterprises of Transcarpathia

\begin{tabular}{|c|c|c|c|c|c|c|c|c|c|}
\hline \multirow[b]{2}{*}{ Indicator } & \multicolumn{8}{|l|}{ Year } & \multirow{2}{*}{$\begin{array}{r}2015 \\
\text { in \% } \\
\text { to } 2006\end{array}$} \\
\hline & 2006 & 2007 & 2008 & 2009 & 2010 & 2011 & 2013 & 2015 & \\
\hline 1 & 2 & 3 & 4 & 5 & 6 & 7 & 8 & 9 & 10 \\
\hline \multicolumn{10}{|c|}{ Winter wheat } \\
\hline $\begin{array}{l}\text { Production, } \\
\text { Thous. } t\end{array}$ & 58,3 & 69,1 & 75,5 & 61,3 & 34,2 & 55,1 & 76,7 & 81,3 & 139,4 \\
\hline $\begin{array}{l}\text { Yield capacity } \\
\text { t/ha }\end{array}$ & 35,0 & 26,0 & 36,8 & 36,3 & 32,8 & 38,8 & 38,7 & 37,5 & 107,1 \\
\hline $\begin{array}{l}\text { Prime cost } \\
\text { 1t, hrn }\end{array}$ & 436,0 & 578,8 & 728,9 & 759,8 & 784,7 & 805,7 & 866,9 & 896,2 & $\begin{array}{ll}\text { in } & 2,1 \\
\text { times } & \end{array}$ \\
\hline $\begin{array}{l}\text { Average sale } \\
\text { price } 1 \mathrm{~T}, \mathrm{hrn}\end{array}$ & 433,1 & 536,7 & 849,8 & 872,1 & 857,6 & 911,6 & 1123,1 & 1422,1 & in 3,3 P \\
\hline
\end{tabular}




\begin{tabular}{|c|c|c|c|c|c|c|c|c|c|}
\hline $\begin{array}{c}\text { Income }(+) \\
\text { Loss }(-) \text { on } \\
1 \text { ha, hrn }\end{array}$ & $-4,7$ & $-64,1$ & 167,4 & 196,0 & 171,5 & 76,4 & 134,7 & 156,7 & $x$ \\
\hline 1 & 2 & 3 & 4 & 5 & 6 & 7 & 8 & 9 & 10 \\
\hline $\begin{array}{l}\text { Level of } \\
\text { profitability } \\
(+) \\
\text { Unprofitabilit } \\
(-), \%\end{array}$ & $-0,7$ & $-7,3$ & 6,7 & $-4,1$ & $-21,1$ & 2,6 & 8,9 & 11,6 & $x$ \\
\hline \multicolumn{10}{|c|}{ Grapes } \\
\hline $\begin{array}{l}\text { Production, } \\
\text { th. } t\end{array}$ & 25,0 & 21,4 & 21,4 & 18,9 & 20,3 & 20,8 & 29,0 & 27,2 & 108,8 \\
\hline $\begin{array}{l}\text { Yield capacity, } \\
\text { t/ha }\end{array}$ & 61,6 & 50,8 & 52,1 & 45,7 & 51,7 & 67,9 & 78,7 & 73,9 & 119,9 \\
\hline Prime cost 1t, hrn & 26122 & 28111 & 31236 & 33897 & 36778 & 35123 & 33245 & 35677 & 136,6 \\
\hline $\begin{array}{l}\text { Average price of } \\
\text { sales } 1 \mathrm{t}, \mathrm{hrn}\end{array}$ & 28888 & 30456 & 33456 & 35466 & 39676 & 38777 & 39456 & 41345 & 143,1 \\
\hline $\begin{array}{l}\text { Income (+), } \\
\text { losses(-) on } \\
1 \text { ha, hrn }\end{array}$ & 101,9 & 88,8 & $91, .4$ & 84,3 & 98,5 & 125,8 & 176,5 & 155,4 & 152.5 \\
\hline $\begin{array}{l}\text { Level of } \\
\text { profitability } \\
(+) \\
\text { Unprofitability } \\
(-), \%\end{array}$ & 20,3 & 18,9 & 17,3 & 16,1 & 15,4 & 23,4 & 54,3 & 45,7 & $\ln 2,25 \mathrm{t}$ \\
\hline \multicolumn{10}{|c|}{ Milk } \\
\hline $\begin{array}{l}\text { Production, } \\
\text { th. } t\end{array}$ & 7,2 & 6,6 & 5,7 & 6,5 & 6,0 & 2,6 & 4,9 & 3,5 & 48,6 \\
\hline $\begin{array}{l}\text { Prime cost 1t, } \\
\text { hrn }\end{array}$ & 1189,9 & 1202,5 & 1574,2 & 1798,0 & 1859,3 & 1955,1 & 1989,5 & 2010,1 & 177,3 \\
\hline $\begin{array}{l}\text { Average price of } \\
\text { sales } 1 \mathrm{t}, \mathrm{hrn}\end{array}$ & 940,2 & 940,4 & 1408,7 & 1661,0 & 1579,0 & 1722,1 & 1861,8 & 1979,3 & $\ln 2,1$ \\
\hline $\begin{array}{l}\text { Income (+), } \\
\text { losses (-) } \\
1 \text { ha, hrn }\end{array}$ & $-4,1$ & $-8,9$ & $-6,4$ & $-3,6$ & $-17,5$ & $-1,9$ & 2,7 & 5,6 & $x$ \\
\hline $\begin{array}{l}\text { Level of } \\
\text { profitability } \\
(+) \\
\text { Unprofitability } \\
(-), \%\end{array}$ & $-1,4$ & $-3,8$ & $-2,6$ & $-1,2$ & $-8,0$ & $-3,2$ & 1,1 & 0,3 & $x$ \\
\hline \multicolumn{10}{|c|}{ Pig flesh(pork) } \\
\hline $\begin{array}{l}\text { Production, } \\
\text { th. } t\end{array}$ & 0,7 & 1,3 & 1,2 & 1,3 & 1,5 & 2,3 & 0,6 & 0,1 & 14,3 \\
\hline $\begin{array}{l}\text { Average daily } \\
\text { daily growth }\end{array}$ & 374 & 376 & 384 & 404 & 405 & 388 & 351 & 310 & 82,9 \\
\hline
\end{tabular}




\begin{tabular}{|c|c|c|c|c|c|c|c|c|c|}
\hline g & & & & & & & & & \\
\hline $\begin{array}{l}\text { Prime cost } \\
\text { 1t, hrn }\end{array}$ & 6790,1 & 7902,6 & 8174,2 & 10498,0 & 11597,4 & 13456,1 & 14222,1 & 15444,1 & in $2,3 \mathrm{P}$ \\
\hline $\begin{array}{l}\text { Average price of } \\
\text { sales } 1 \mathrm{t}, \mathrm{hrn}\end{array}$ & 5346,6 & 4344,2 & 4899,4 & 7988,7 & 7866,5 & 8856,3 & 9123,2 & 9776,4 & 182,8 \\
\hline 1 & 2 & 3 & 4 & 5 & 6 & 7 & 8 & 9 & 10 \\
\hline $\begin{array}{l}\text { Income (+), } \\
\text { losses }(-) \text { on } 1 \text { ha, } \\
\text { hrn }\end{array}$ & \begin{tabular}{|l|}
$-199,7$ \\
\end{tabular} & $-456,6$ & $-712,3$ & $-500,5$ & $-911,1$ & 1023,3 & 1122,2 & 1333,4 & $x$ \\
\hline $\begin{array}{l}\text { Level of } \\
\text { profitability } \\
(+), \\
\text { Unprofitability } \\
(-), \%\end{array}$ & $-2,3$ & $-7,7$ & $-8,5$ & $-7,3$ & $-9,7$ & $-5,3$ & $-3,2$ & $-1,2$ & $x$ \\
\hline
\end{tabular}

Analysis of dynamics of the level of profitability of production of the main types of agricultural production in the agrarian organizations of the region witnesses that the most profitable is the plants production. The major part of income that the enterprises get from selling wheat and wine, the increase of growth on which have lately conditioned the price increase on the given goods. The main types of animal farming goods, from the sale of which the agrarian enterprises get their profit are milk and pork.

The achieved level of the agrarian production efficiency of the crops is insufficient to provide the wide reproduction and needs the further development with the withdrawing of the additional investments and innovative solutions.

In the conditions of the state of the agrarian sphere, a very important is a diversification of the instruments of the credits support of agrarian producers, accumulation of their own investment resources by the subject of the agrarian business, implementation of the optimal schemes of taxation and insurance taking into consideration the ecological factor when working out the investment strategy of the powerful agro industrial associations. [15].

The creation of techno parks and other innovative structures on the regional level will contribute to activation of innovative activity in agriculture on the stages of development, approbation and reproduction of novation. Creation of the new scientific-technological structures of the techno park type can become an important factor of development of innovative infrastructure of the agrarian production.

A modern technological park is being viewed as a form of territorial integration of science, education and production in a form of the combination of scientific organizations, educational institutions and production enterprises or their departments with the aim to speed up the elaborations and implementation of the scientific-technical and technics-technological achievements.

Namely the technological parks can become the very organizational structures where the applied and fundamental scientific investigations are being implemented into practice and the comfortable conditions for the realization of the process of mastering new ideas and inventions are being created.

At the same time having a considerable potential for development of innovative activity in Ukraine there function only 16 techno parks , 5 of which had been created lately, and actually work only 4 [3]. 
Unfortunately, not all the technological parks became the regional poles of growth. Thus, some separate techno parks of Ukraine don't use their potential which enables modernization and renovation of the material-technical bases of the scientific institutions and educational institutions, improving the system of control of technological processes in production, creating new equipment for the development of Nano and bio technologies and so on. Under the condition of widening the regional set of technological parks, they can provide in Ukraine the creation and production of the highly technological production both - for the demands of the home and foreign markets.

Realization of the techno parks concept of innovative development of the regions is possible only under the conditions of coordinated activity and cooperation of science, higher school, enterprises of different property forms, state and local bodies of administration.

The determinant role in the development of technological parks belongs to the state, which forms the strategy of innovative development and leads the policy of involving the innovative activity of the business entities.

The state has to provide the direct financing of the venture scientific-technical projects, their easy term loan and taxation, setting the corresponding tariff rates on the municipal facilities for the scientific , special regime of foreign economic activity in the techno park sphere and so on.

The basic directions of increasing the volumes of production of plants' and animals' goods, improving their quality and enlargement of recoupment of expenses is perfection of the agriculture systems, search of the ways to reduce the energy demands, implement the effective resource preserving technologies of growing the agricultural crops and keeping the animals. [2].

One of directions to stimulate the economic activity on the regional level, the involvement of foreign investments, achieving the innovative quality of the regional economics is the creation of the territorialhousehold formations, nowadays in the form of techno parks. [1].

The directions of the development of the agriculture branch is based on the results of investigations on the production of the grain crops using the traditional and energy preserving technologies, which made it possible to establish that when introducing the energy keeping technology from 1 ha of the seeds additionally is possible to get $300-315 \mathrm{hrn}$ of income or $25-28 \%$ more that when growing the winter wheat using the traditional technology with tilling. The calculations, made with the help of the elaborated financial scheme of financial cash flow had showed, that the period of investments returns from the purchase of technics, needed for the growing of winter wheat with the minimal soil cultivation will make up 47 mon., while using the traditional technology - 58 months.

Innovative development of the branch of the dairy cattle breeding in Transcarpathia foresees the introduction of the technology of the non-bended keeping of the highly productive cows and young stock in the stalls using the modern equipment for animals keeping. Feeding the cows and cattle young stock has to be done with the use of the balanced feeding mixes alongside with the regular calving, and milk production during a year with the maximum use of the natural forage lands.

The development of the pig breeding branch foresees implementation of the flow production of pork using the full-filling feed stuff.

The agrarian enterprises are provided with the machines. For the machine-tractor vehicle renovation on the level of the technological needs, according to the calculations of scientists of SNC "Institute of Agrarian Economics", each year there should be bought the machines and equipment on the sum of $15 \mathrm{mlrd}$ hrn. [10].

In the conditions of the limitation of the financial resources in the agrarian formations there rises a question of the turn implementation of the innovative measures. In order to solve this problem we propose to optimize the productive structure of the enterprise which gives the opportunity to use a systematic approach to the assessment of efficiency of innovative measures, prognosis of the different situations of agrarian formations development and define the optimal parameters of their productive systems. [14]. 
A necessary condition of forming the innovative economics is also the development of science, as science -is such a type of a human activity, which foresees not only the accumulation and transfer of knowledge, and also the production of the new ones. Modern innovations, inventions completely change the lives of people. They also stimulate the economic growth and its qualitative new level of development. Science more than ever before is in demand, needed for the welfare, safety, health, environment preserving and quality of life. [8].

\section{Conclusions.}

The main problem of innovative strategy realization of the increase of the qualitative functioning of the agricultural enterprises lies in the fact that the tempo of development and the structure of the sector of the agrarian researches and elaborations don't fully correspond to the needs of agriculture and constantly growing demand on the new modern technologies from the side of the separate segments of the business sector. Alongside with this, the proposed scientific results don't find implementation under the reason of unbalanced innovative system, and as a result of a general low reacceptance to innovations by the business sector, its low profitability.

Despite all the problems of innovative development, attractiveness of the agrarian sphere becomes more noticeable. There are wide perspectives for the agrarian sphere of Transcarpathia because of the threat of the world food crises, increase of demand on the biofuel, absence of possibility to widen the crop acreage and grow the productivity of agriculture of the main agrarian countries.

However, the most considerable reasons of slowing down the process of agro innovations implementation is the insufficient level of the financial provision of enterprises, low credits acceptability and state support for modernization of the agrarian branch, underdevelopment of the information provision of innovative process system.

That's why for the financial provision of agrarian sphere innovative development it is necessary to:

- Concentrate the capital on the priority directions of development, especially on education, science, progressive technologies, business activity on the market of science intensive production;

- Provide organization of a competitive production of agrarian goods production, which is possible due to concentration of investments in the priority spheres, besides due to realization of investments into the human capital development, which is the basis of production and implementation of the new knowledge of organizational, technological, economic and ecological orientation;

- Reorient the investments into the development of the agriculture branches with the comparatively high intensity of production, which need today the most rapid renovation on the new technic-technological bases, provide the creation of the additional work places in the rural areas and production of the import substituting goods;

- Implement the investment- innovative projects of building the industrial objects on recycling of energy products and biofuel production, which will contribute to the emission of the alternative types of clear fuel, utilization of the overflow of the produced agricultural goods, and intermediate goods of the industrial production, creation of the new working places, rural population income increase, and budget revenue..

\section{Bibliography}

1. Balyan A.V. Regional systems of foreign investment to Transcaarpathia. // Economics of AIC . 2004. - №7. - P.152.

2. Gordiychuk A.I. Theoretical backgrounds of innovative development of agrarian sphere / A.I. Gordiychuk // Scientific journal of NAU. - 2008. -Ed. 131. - P.77-80.

3. Gordiyenko V.P. Innovative development of the regions on the basis of technoparks concept //Economic scope. - 2011. - № 46. - P. 37-44. 
4. Datziy O.I. Financial provision of innovations in the agro industrial complex of Ukraine // Problems of investment-innovative development. - 2011. - № 1. - P. 65-76.

5. Innovative development of economics and directions of its speeding. Scientific report $/$ Y.M.Bazhal , I.V. Odotyuk , M.S. Danko , O.O. Lapko and others.; pub. V.P. Aleksandrova / NAS of Ukraine; Institute of economics prognosis.. - K.: 2008. - № 9. - P. 30-37.

6. Kot O.V. Theoretical aspects of innovative development of agrarian sector of economics and its organization-economic securing / O.V. Kot // Problems in agrarian formations and their consequences. // Problems of investment-innovative development. - 2011. - № 1. - P. 57-63.

7. Scientific foundations of agro industrial production in the forest-steppe zone of Ukraine. /Red.: M.V. Zubetz and others . - K.: Logos, 2004. - P.74.

8. Obama B.: Science is necessary as never before - available at access mode: http:// trvscience.ru/2009/05/26/obama-nauka-nuzhna-kak-nikogda-ranshe-2/.

9. Official web-сайт of Ministry of agrarian policy and provision of Ukraine [digital source]. - Access mode: http://www.minagro.gov.ua..

10. Sabluk P.T. Structural-innovative moves in the agrarian sector of Ukraine as the factor of their social -economic growth // Economics of AIC . - 2004. - №6. - P.3-8.

11. Santo B. Innovations as the means of economic development: transl. from Hungarian /B.Santo. - M.: Progress1990. - 296c.

12. Statistic yearly annual of Transcarpathia over 2015. Statistics headquarters in Transcarpathia. Uzhgorod 2016y.

13. Tregobchuk V. Innovative- investment development of the national AIC: problems, directions and mechanisms / V. Tregobchuk // Economics of Ukraine. - 2006. - №2.- P. 4-12.

14. Chaban V.G. Innovations as the condition of increase of agrarian sector competitiveness / V.G. Chaban // Economics of AIC. - 2006. - №7. - P. 68-72.

15. Shkilyov O.V. Innovative development of production of economic prognosis. 2002. - 80p. 